\title{
TOPIC AND FOCUS: TWO STRUCTURAL POSITIONS ASSOCIATED WITH LOGICAL FUNCTIONS IN THE LEFT PERIPHERY OF THE HUNGARIAN SENTENCE
}

\author{
KATALIN É. KISS \\ Research Institute for Linguistics \\ Hungarian Academy of Sciences \\ Benczúr utca 33. \\ H-1068 Budapest \\ Hungary \\ ekiss@nytud.hu
}

Abstract: The paper explicates the notions of topic, contrastive topic, and focus as used in the analysis of Hungarian. Based on distributional criteria, topic and focus are claimed to represent distinct structural positions in the left periphery of the Hungarian sentence, associated with logical rather than discourse functions. The topic is interpreted as the logical subject of predication. The focus is analyzed as a derived main predicate, specifying the referential content of the set denoted by the backgrounded post-focus section of the sentence. The exhaustivity associated with the focus, and the existential presupposition associated with the background are shown to be properties following from their specificational predication relation.

Keywords: topic, focus, contrastive topic, exhaustive identification

\section{Introduction}

My interpretation of the notions topic, contrastive topic, and focus reflects the usage of these terms in Hungarian generative grammar. ${ }^{1}$ In Hungarian linguistics, these terms denote grammatical functions linked to invariant structural positions and associated with invariant logicalsemantic roles.

${ }^{1}$ See Horvath (1976); É. Kiss (1977); Szabolcsi (1981); É. Kiss (1981); Szabolcsi (1983); Horvath (1986); Kenesei (1986); É. Kiss (1987); Kiefer-É. Kiss (1994); Brody (1990; 1995); É. Kiss (1998; 2002); Surányi (2002); Gyuris (2003); É. Kiss -Gyuris (2003); Maleczki (2004); Olsvay (2004); Horvath (2005); Bende-Farkas (2006); É. Kiss (2006), etc., and for partially different views, Szendrői (2003) and Wedgwood (2005). 


\section{Topic}

An eventuality is usually described in Hungarian as a statement (a predicate) about one of its participants (the topic). The topic-predicate articulation is manifested on the syntactic, prosodic, and semantic levels alike:

(1) The topic is an XP extracted from the functionally extended verb phrase into the left periphery of the sentence. It precedes the pitch accent that marks the left edge of the functionally extended verb phrase in Hungarian. It is interpreted as the logical subject of predication.

On the syntactic level, the topic is an argument preposed from the maximally extended verb phrase into clause-initial position, with a trace/copy in the vP. Sentence adverbials base-generated external to the maximal verbal projection are not topics. Referential locative and temporal adverbials, however, can be analyzed not only as sentence adverbials but also as optional arguments binding traces in the vP, hence they can function as topics in the left periphery.

The landing site of topics is the specifier of the functional projection TopP. In the case of multiple topicalization, the iteration of TopP is assumed. The relative order of topics and sentence adverbials is free. ${ }^{2}$

The topic functions as the logical subject; it presents the individual that the sentence predicates about. In a multiple topic construction, the topicalized arguments fulfill the role of the logical subject of predication together; it is their relation that is predicated about.

In accordance with its function, the logical subject must be a referring expression associated with an existential presupposition. Names, definite noun phrases, and specific indefinite noun phrases (or PPs subsuming such a noun phrase) are all possible topics, irrespective of their subject, object, or prepositional object status. For example:

(2) (a) Az egyik agresszív játékost ki- állították. the one aggressive player-acc out sent-they 'One of the aggressive players was sent out.'

${ }^{2}$ Frascarelli and Hinterhölzl (2007) argue that the order of topics is not free but shows the following pattern: aboutness $>$ contrastive $>$ familiar. Frey (2005) claims that sentence adverbials must follow the topic in German. The observance of these constraints perhaps yields slightly preferred options in Hungarian; still, every permutation of the various kinds of topics and sentence adverbials in the preverbal domain is grammatical in this language. 
(b) A csapat szállodája előtt fotóriporterek gyülekeztek. the team's hotel before cameramen-nom gathered 'In front of the team's hotel, cameramen were gathering.'

Neither universal quantifiers, nor monotone decreasing quantifiers can be topicalized. (Nominals with a numeral modifier, or with the determiner sok 'many' or legtöbb 'most', on the other hand, can be forced into referential readings under which they are possible topics.) Noun phrases which are necessarily non-specific - either for syntactic reasons, having no determiner as in (3a), or for semantic reasons, being in an intensional context as in (3b) - are not fit for the logical subject role, either. (These constraints are lifted in the case of contrastive topics, to be discussed in section 3.) Cf.:

(3) (a) *Repedések látszólag keletkeztek a földrengés után. cracks apparently formed the earthquake after 'Cracks apparently formed after the earthquake.'

(b) *Egy amerikai milliomosra valószínüleg vár Mari. an American millionaire-for probably waits Mary-nom 'An American millionaire, probably Mary waits for.'

The specificity requirement associated with the Hungarian topic only means that its referent must exist in the universe of discourse (or at least in the speaker's universe) independently of the event described in the sentence; however, it need not be uniquely identifiable. Thus valaki 'somebody' and valami 'something' are also topicalizable:

(4) Valaki el- lopta a biciklimet!

somebody prt stole my bicycle

'Somebody stole my bicycle!'

The topic of the Hungarian sentence need not be contextually given. Allnew sentences can also have a topic. For example, a large part of the headlines in newspapers display a topic-predicate articulation:

(5) Az európai baromfiállomány egyötöde szalmonellával fertőzött.

the European poultry one-fifth-poss salmonella-with infected

'One fifth of European poultry is infected with salmonella.'

At the same time, all-new sentences can also be topicless: 
(6) Ki- zárja a szlovák kormánypártot az EP szocialista frakciója. prt excludes the Slovak governing-party-acc the EP socialist fraction-poss 'The socialist fraction of the EP excludes the Slovak governing party.'

\section{Contrastive topic}

If the topic is not only stressed but is also pronounced with a fall-rise denoting a contrast (marked by the symbol ${ }^{\vee}$ ), the referentiality requirement associated with it is apparently lifted. Thus non-specific indefinites and quantified noun phrases can also be contrastively topicalized.

(7) (a) ${ }^{\vee}$ Repedések nem keletkeztek a földrengés után. cracks not formed the earthquake after 'Cracks didn't form after the earthquake.'

(b) ${ }^{\vee}$ Minden dolgozatot CSAK KÉT DIÁK írt meg határidöre. every paper-acc only two student wrote prt deadline-by 'All the papers were only written by two students by the deadline.'

A non-contrastive topic does not even have to be a noun phrase; it can also be a verbal particle (8a), a predicative adjective or nominal (8b), or even a verb (8c). V-topicalization involves copying instead of movement; the verb is represented in Spec,TopP by an (elliptic?) infinitive phrase, and both copies are pronounced.

(8) (a) ${ }^{\vee}$ Fel LIFTEN megyek, le GYLOG.

up elevator-by go-I down foot-on

'Up I go by elevator, down I go on foot.'

(b) ${ }^{\vee}$ Biciklit SOKAN vásároltak. bicycle-acc many bought

'A bicycle, many people bought.'

(c) ${ }^{\vee}$ Enni EveTt Péter egy keveset.

eat-inf ate Peter-nom a little-acc

'As for eating, Peter ate a little.'

In É. Kiss-Gyuris (2003) we propose an analysis that assimilates contrastive topics to ordinary topics as defined in (1). The proposal is based on Szabolcsi's (1983) idea that contrast is a means of individuation, i.e., non-individual-denoting expressions are understood as distinct semantic 
objects if they are contrasted. (Think of examples like TRABANTTAL jöttem, nem AUTÓVAL 'BY TRABANT I came, not BY CAR' - expressing that the speaker considers the property 'Trabant' and the property 'car' not to be overlapping.) Non-individual-denoting expressions individuated by contrast denote properties which the rest of the sentence predicates a (higher-order) property about. A quantifier functioning as a contrastive topic denotes a property of plural individuals, and its apparent narrow scope arises from the fact that it is considered to be a predicate over a variable inherent in the lexical representation of the verb. In $(8 b)$, for example, the subject of predication is the property 'bicycle', which is possibly embodied by different bicycles for each of the many persons in question.

\section{Focus}

The syntactic, semantic and prosodic properties of the focus of the Hungarian sentence are summarized in (9):

(9) The focus is an immediately preverbal constituent, expressing exhaustive identification, bearing a pitch accent.

Syntactically, the Hungarian focus is an XP occupying an invariant A-bar position, identified by Brody (1990) as the specifier of a FocP. The finite $\mathrm{V}$, which follows the verbal particle in neutral sentences (10a), is leftadjacent to the focus (10b), which may be due to $\mathrm{V}$ movement across the particle - into the head of a Non-NeutralP according to Olsvay (2004). FocP is subsumed by TopP.

(10) (a) [TP Össze veszett János Marival] out fell John Mary-with 'John fell out with Mary.'

(b) [TopP János [FocP MARIVAL [NNP veszett [TP össze $\left.\left.\left.\left.t_{\mathrm{V}}\right]\right]\right]\right]$ 'It is stated about John that it was Mary that he fell out with.'

The functional projection harboring the focus constituent seems iterable, with the $\mathrm{V}$ moving up cyclically into a position adjacent to the highest focus: 
(11) [FocP CSAK JÁNOS [NNP olvasott [FocP CSAK EGY CIKKET [NNP $t_{\mathrm{V}}\left[\mathrm{TP}\right.$ el $\left.\left.\left.\left.\left.t_{\mathrm{V}}\right]\right]\right]\right]\right]$ only John read only one paper-acc prt 'Only John read only one paper.'

Certain types of elements, e.g., wh-phrases, phrases modified by only, or monotone decreasing quantifiers, are obligatorily focussed. Universal quantifiers, and phrases associated with also and even are barred from focus position.

Spec,FocP is filled by an argument or a predicative adverbial via movement constrained in the usual way. The focus binds a variable, and displays a version of the Weak Crossover effect. It also licensces a parasitic gap:

(12) KÉT VENDÉGET $i$ hívtam meg $t_{i}$ anélkül, hogy ismernék $p g$. two guest-acc invited-I prt without-it that know-I

'It was two guests that I invited without knowing.'

The Hungarian focus expresses exhaustive identification. Szabolcsi (1981) describes its meaning with the formula illustrated in (13b):

(13) (a) PÉTER aludt a padlón.

Peter slept the floor-on

'It was Peter who slept on the floor.'

(b) 'for every $x, x$ slept on the floor iff $x=$ Péter'

The universal quantifier in (13b) is to be interpreted on a relevant set. Evidence of the [+ exhaustive] feature of focus is provided by the fact that (13a) and (14a) cannot be simultaneously true, i.e., (13a) is not a consequence of (14a) but contradicts it. It is the negation of (13a) that can be coordinated with (14a):

(14) (a) PÉTER És PÁL aludt a padlón.

Peter and Paul slept the floor-on

'It was Peter and Paul who slept on the floor.'

(b) Nem PÉTer aludt a padlón, hanem PÉTER És PÁL (aludt a padlón).

'It wasn't Peter who slept on the floor but it was Peter and Paul.'

Example (15) does not refute the exhaustivity of focus; its focus provides a partially specified exhaustive list of the individuals for which the TP holds: 
(15) Többek között PÉTER aludt a padlón. among others Peter slept the floor-on 'It was Peter, among others, who slept on the floor.'

Kenesei (1986) attributes the [+ exhaustive] feature of focus to an iota operator, which performs identification - and thereby also exclusion - in a restricted domain. Szabolcsi (1994) basically adopts Kenesei's notion of focus; however, she proposes to change the formalism in such a way that it can also handle plurals:

(16) $\lambda z \lambda P[z=\iota x[P(x) \& V y[P(y) \rightarrow y \leq x]]]$

In É. Kiss (1998) I claimed that the preverbal focus represents the value of a focus operator operating on a set of alternatives for which the predicate can potentially hold, exhaustively identifying the subset for which the predicate actually holds. Horvath (2005) assumes an Exhaustive Identification Operator (EIOp) merged with the focus phrase. Bende-Farkas (2006) identifies this operator semantically as a maximality operator.

In my current view, influenced by Higgins (1973) and Huber (2000), the focus is a specificational predicate, representing the main assertion in the sentence. It is predicated of the background, an open sentence corresponding to the post-focus section of the clause. The focus specifies the referential content of the set denoted by this open sentence.

This analysis predicts not only the exhaustivity associated with focus, but also the existential presupposition associated with the background. Exhaustivity is entailed by the specificational predicate role of focus: the specification of the referential content of a set implies the exhaustive listing of its elements. The existential presupposition of the background follows from the fact that only the content of an existing set can be referentially identified. Universal quantifiers are barred from focus position because they cannot function as predicates.

This analysis also predicts the possibility of double negation in Hungarian: either the predicate of the open sentence corresponding to the background, or the focus, or both can be negated:

(17) (a) János [FocP MARIT [NegP nem [NNP hívta [TP meg]]]]

John Mary-acc not invited prt

'It was Mary who John didn't invite.'

(b) János [NegP nem [FocP MARIT [NNP hívta [TP meg]]]]

'It wasn't Mary who John invited.' 
(c) János [NegP nem [FocP MARIT [NegP nem [NNP hívta [TP meg]]]]] 'It wasn't Mary who John didn't invite.'

The focus has two distinctive prosodic features: it bears a pitch accent, and destresses the $\mathrm{V}$ adjacent to it. The focus following a negative particle is cliticized to the particle. A focus may also be destressed also when preceded by a wide-scope universal quantifier.

As is clear from the above, the Hungarian preverbal focus cannot be identified with the carrier of new information. New information does not have to be focussed. A constituent giving a non-exhaustive answer to a $w h$-phrase usually remains in situ (18b), or is formulated as a contrastive topic (18c):

(18) (a) KIT kérhetnénk fel a feladatra?

'Who could we ask for the job?'

(b) Fel- kérhetnénk Pétert.

prt ask-cond-1pl Peter-acc

'We could ask Peter.'

(c) ${ }^{\vee}$ Pétert fel- kérhetnénk.

Peter-acc prt ask-cond-1pl

'Peter, we could ask.'

In focus constructions there is a containment relation between the focus and new information. The carrier of new information can be either smaller or larger than the focus XP, and in the former case it must be contained in the focus XP (19b), while in the latter case it must subsume the focus XP (20b) (Bende-Farkas 2006):

(19) (a) MELYIK CSAPAT nyerte meg a világbajnokságot?

which team won prt the world-cup

'Which team won the world cup?'

(b) Az OLASZ CSAPAT (nyerte meg a világbajnokságot).

the Italian team won prt the world-cup

'The Italian team.'

(20) (a) Mi történt?

'What happened?'

(b) AZ OLASZ CSAPAT nyerte meg a világbajnokságot.

the Italian team won prt the world-cup

'It was the Italian team that won the world cup.' 


\section{Summary}

It has been argued that the topic and the focus represent two distinct, optionally filled structural positions in the left periphery of the Hungarian sentence, associated with logical rather than discourse functions. The topic functions as the logical subject of predication. Non-individualdenoting expressions can also be made suitable for the logical subject role if they are individuated by contrast. The focus expresses exhaustive identification; it functions as a derived main predicate, specifying the referential content of the set determined by the backgrounded post-focus part of the sentence.

\section{References}

Bende-Farkas, Ágnes 2006. Comparing English and Hungarian focus. Ms. Universität Stuttgart.

Brody, Michael 1990. Some remarks on the focus field in Hungarian. In: UCL Working Papers in Linguistics $2: 201-26$.

Brody, Michael 1995. Focus and Checking Theory. In: István Kenesei (ed.): Approaches to Hungarian 5 (Levels and structures), 29-43. JATEPress, Szeged.

É. Kiss, Katalin 1977. Topic and focus in Hungarian syntax. In: Montreal Working Papers in Linguistics $8: 1-42$.

É. Kiss, Katalin 1981. Syntactic relations in Hungarian, a "free" word order language. In: Linguistic Inquiry $12: 185-215$.

É. Kiss, Katalin 1987. Configurationality in Hungarian. Akadémiai Kiadó, Budapest.

É. Kiss, Katalin 1998. Identificational focus versus information focus. In: Language $74: 245-73$.

É. Kiss, Katalin 2002. The syntax of Hungarian. Cambridge University Press, Cambridge.

É. Kiss, Katalin 2006. Focussing as predication. In: Valeria Molnár-Susanne Winkler (eds): The architecture of focus, 169-96. Mouton de Gruyter, Berlin \& New York.

É. Kiss, Katalin - Beáta Gyuris 2003. Apparent scope inversion under the rise fall contour. In: Acta Linguistica Hungarica $50: 371-404$.

Frascarelli, Mara - Roland Hinterhölzl 2007. Types of topics in German and Italian. In: Kerstin Schwabe-Susanne Winkler (eds): On information structure, meaning and form, 87-116. John Benjamins, Amsterdam \& Philadelphia.

Frey, Werner 2005. Pragmatic properties of certain German and English left peripheral constructions. In: Linguistics $43: 89-129$.

Gyuris, Beáta 2003. The semantics of contrastive topics in Hungarian. Doctoral dissertation, Theoretical Linguistics Program, Eötvös Loránd University, Budapest.

Higgins, Roger F. 1973. The pseudo-cleft construction in English. Doctoral dissertation, MIT. 
Horvath, Julia 1976. Focus in Hungarian and the $\mathrm{X}^{\prime}$ notation. In: Linguistic Analysis $2: 175-97$

Horvath, Julia 1986. Focus in the theory of grammar and the syntax of Hungarian. Foris, Dordrecht.

Horvath, Julia 2005. Is "Focus Movement" driven by stress? In: Christopher PiñónPéter Siptár (eds): Approaches to Hungarian 9 (Papers from the Düsseldorf conference), 131-58. Akadémiai Kiadó, Budapest.

Huber, Stefan 2000. Es-Clefts und det-Clefts. Zur Syntax, Semantik und Informationsstruktur von Spaltsätzen im Deutschen und Schwedischen. Almqvist \& Wiksell, Stockholm.

Kenesei, István 1986. On the logic of Hungarian word order. In: Werner AbrahamSjaak de Meij (eds): Topic, focus, and configurationality, 143-59. John Benjamins, Amsterdam.

Kiefer, Ferenc - Katalin É. Kiss (eds) 1994. The syntactic structure of Hungarian. Academic Press, San Diego CA.

Maleczki, Márta 2004. The semantic analysis of thetic judgments. In: László Hunyadi - György Rákosi - Enikő Tóth (eds): The Eighth Symposium on Logic and Language. Preliminary papers, 107-18. University of Debrecen, Debrecen.

Olsvay, Csaba 2004. The Hungarian verbal complex: An alternative approach. In: Katalin É. Kiss - Henk van Riemsdijk (eds): Verb clusters. A study of Hungarian, German and Dutch, 290-333. John Benjamins, Amsterdam \& Philadelphia.

Surányi, Balázs 2002. Multiple operator movements in Hungarian. Doctoral dissertation, LOT, Utrecht.

Szabolcsi, Anna 1981. The semantics of topic-focus articulation. In: Jeroen Groenendijk - Theo Janssen - Martin Stokhof (eds): Formal methods in the study of language, 513-41. Matematisch Centrum, Amsterdam.

Szabolcsi, Anna 1983. Focusing properties, or the trap of first order. In: Theoretical Linguistics $10: 125-45$.

Szabolcsi, Anna 1994. All quantifiers are not equal: The case of focus. In: Acta Linguistica Hungarica $42: 171-87$.

Szendröi, Kriszta 2003. A stress-based approach to the syntax of Hungarian focus. In: The Linguistic Review $20: 37-78$.

Wedgwood, Daniel 2005. Shifting the focus: From static structures to the dynamics of interpretation. Elsevier, Amsterdam. 